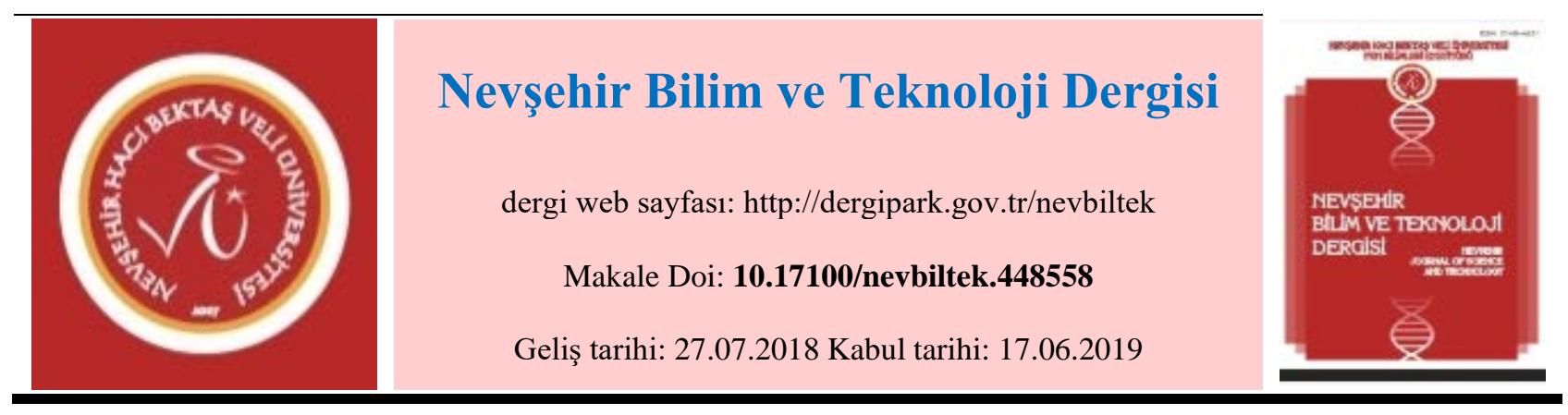

\title{
Düşük Maliyetli İHA ile Yüksek Çözünürlüklü SYM Üretimi 1
}

\author{
Nizar POLAT ${ }^{1}$, Murat UYSAL ${ }^{2}$, Mehmet Ali DERELI ${ }^{3 *}$ \\ ${ }^{1}$ Harran Üniversitesi, Mühendislik Fakültesi, Harita Mühendisliği Bölümü, Şanlıurfa \\ ORCID ID: 0000-0002-6061-7796 \\ ${ }^{2}$ Afyon Kocatepe Üniversitesi, Mühendislik Fakültesi, Harita Mühendisliği Bölümü, Afyonkarahisar \\ ORCID ID: 0000-0001-5202-4387 \\ ${ }^{2}$ Giresun Üniversitesi, Mühendislik Fakültesi, Harita Mühendisliği Bölümü, Giresun \\ ORCID ID0000-0003-0575-1316
}

Öz

Günümüzde İnsansız Hava Araçları (IHHA'lar) pek çok uygulamada farklı amaçlar için yaygın olarak kullanılmaktadır. Ancak faydaları, dijital kamera, GPS veya lazer tarayıcı gibi ekipmanların entegrasyon yetenekleri nedeniyle tamamen tespit edilememektedir. Bu çalışmanın ana konusu Afyon Kocatepe Üniversitesi Kampüsü’nde Sayısal Yüzey Modeli (SYM) üretimi yoluyla coğrafi konumlu kameralar için entegre İHA'ların performansının değerlendirilmesidir. Bu amaçla 5 yer kontrol noktası ve 12 kontrol noktası işaretlenmiş ve RTK ile incelenmiştir. Daha sonra bir fotogrametrik uçuş planı gerçekleştirilmiş ve 120 m'lik bir yükseklikten, 274 hava fotoğrafları \% 80'lik bir bindirme oranı ile çekilmiştir. Görüntü işlemeden sonra, $50 \mathrm{~cm}$ piksel boyutuna sahip yüksek çözünürlüklü bir SYM üretilmiş ve SYM'nin doğruluğu $5 \mathrm{~cm}$ olarak hesaplanmıştır. Çalışmanın sonucu olarak, İHA fotogrametrisi ile gerçekleştirilen harita üretimi, araştırma ve diğer bazı mühendislik uygulamalarında düşük maliyet, zaman tasarrufu ve minimum saha çalışmasının avantajları ile birlikte kullanılabileceğini göstermiştir.

Anahtar Kelimeler: İHA, SfM Nokta Bulutu, SYM

\section{High Resolution DSM Generation with Low Cost UAV}

\begin{abstract}
Nowadays Unmanned Aerial Vehicles (UAVs) are widely used in many applications for different purposes. Their benefits however are not entirely detected due to the integration capabilities of other equipment such as; digital camera, GPS, or laser scanner. The main scope of this paper is evaluating performance of cameras integrated UAV for geomatics applications by the way of Digital Surface Model (DSM) generation in Afyon Kocatepe University Campus area. For this purpose, 5 ground control points and 12 check points are marked and surveyed with RTK. Then a photogrammetric flight plan is performed and from an altitude of $120 \mathrm{~m}, 274$ aerial photographs are captured with an $80 \%$ overlap rate. After image processing, a high resolution DSM with a $50 \mathrm{~cm}$ pixel size was generated and the accuracy of the generated DSM was calculated as $5 \mathrm{~cm}$. The outcomes of the study show that it is possible to use the UAV Photogrammetry data as map producing, surveying, and some other engineering applications with the advantages of low-cost, time conservation, and minimum field work.
\end{abstract}

Keywords: UAV, SfM Point Cloud, DSM

\footnotetext{
${ }^{1}$ Bu çalışma, Haziran 2018'de Giresun Üniversitesinde gerçekleştirilen 1. Uluslararası Teknoloji Bilimleri ve Tasarım (ITESDES 2018) Sempozyumu'nda sunulmuş bildirinin genişletilmiş halidir.

Sorumlu yazar e-mail: mehmet.dereli@giresun.edu.tr
} 


\section{Giriş}

Günümüzde gelişmiş harita mühendisliği araçlarına dayanan dokümantasyon teknolojileri, hızlanma, kesinlik, maliyet azaltma ve kısa, sürdürülebilirlik açısından güncellenen haritalarda önemli bir destek sunmaktadır. İnsansız Hava Araçları'nın (İHA) kullanımı, yüksek detay değeriyle neredeyse yeni potansiyeller sunmaktadır ve bağlam, geleneksel karasal tarama teknikleri için yeterli erişime sahip olmasa bile, ilgili uygulamalar gerçekten aşamalı olarak uygun hale gelmektedir [1].

İHA yaklaşımı, ortofotolar ve SYM'den türetilen geniş ölçekli coğrafi referanslı bilgiler gibi Coğrafi Bilgi Sistemleri (CBS) izleme uygulamalarına 3B veri sağlayan, mekansal ve zamansal yüksek çözünürlüklü modeller üretmek için yararlı olmaktadır [2 ve 3]. Özellikle küçük yüz ölçümüne sahip alanlarda yükseklik modeli üretimi için kullanım oranı gün geçtikçe artmaktadır [4-7]. Ayrıca yükseklik modeli üretimi için kullanılan geleneksel metotlara da rakip olarak görülmektedir [8]. CBS modellemesi ve analizi için mekânsal veri üreten İHA araştırmasının temel uygulaması, bölgesel, jeolojik, kentsel, tarımsal ve ormancılıktır [9 ve 10]. Ormancılık alanında İHA kullanımı biraz daha özelleşmiştir. Ağaç boyları ve cinslerinin tespitinde ağaç sağlı̆̆ına, ağaç boyu tespitinden orman modellemeye kadar farklı amaçlarda İHA kullanılabilmektedir [11 ve 12]. Çoğunlukla, çıplak-toprak ekstraksiyonu, yoğunluk, yön, eğim, vb. boyunca filtreleme noktası ile nokta bulutları sınıflandırması ve segmentasyonu algoritmaları ile elde edilebilir. Bu çalışmada Afyon Kocatepe Üniversitesi kampüs alanının yüksek çözünürlüklü bir SYM'si üretilmiştir. $50 \mathrm{~cm}$ piksel boyutu ve üretilen SYM'nin doğruluğu $5 \mathrm{~cm}$ olarak hesaplanmıştır.

\section{Materyal ve Metot}

\section{1. Çalışma Alanı ve Veri}

Çalışma alanı olarak Afyon Kocatepe Üniversitesi seçilmiştir. Üniversiteyi içinde barındıran Afyonkarahisar şehrinin büyük bir bölümü Ege bölgesinde bulunmaktadır. Şehrin doğusunda kalan alanlar İç Anadolu bölgesinin özelliklerini göstermektedir. Bununla birlikte güneybatısında kalan çok küçük bir alanda ise Akdeniz bölgesine ait özellikleri görmek mümkün olmaktadır. Afyonkarahisar ili, şehirleri birbirine bağlayan bir kesişim noktası konumundadır. Şehir kuzeyden güneye uzandığından, Batı Anadolu kesimi ile İç Anadolu'yu birleştiren alanın güney parçasını tamamlamaktadır. Bu konumu itibarıyla kuzeybatıyı Anadolu’ya bağlayan önemli merkez durumundadır.

Afyonkarahisar ili bünyesinde 30 binin üzerinde öğrencisi bulunan Afyon Kocatepe Üniversitesi, bölgenin önemli eğitim kurumlarından bir tanesidir. Bu çalışma kapsamında da Afyon Kocatepe Üniversitesi kampüsü çalışma alanı olarak seçilmişsir (Şekil 1).

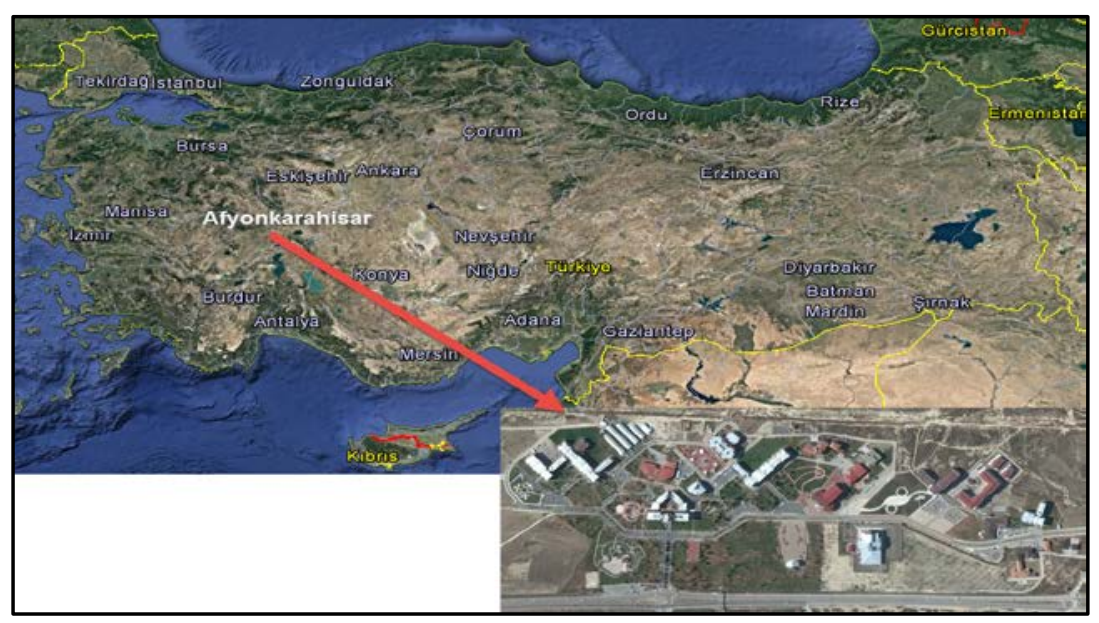

Şekil 1. Çalışma Alanı 
Çalışma için DJI Phantom 4 pro İHA kullanılmıştır. 274 hava fotoğrafları 1100 m x 500 m'lik bir alanda 120 m yüksekliğinden elde edilmiştir. Uçuş yolu Şekil 2'de verilmiştir.

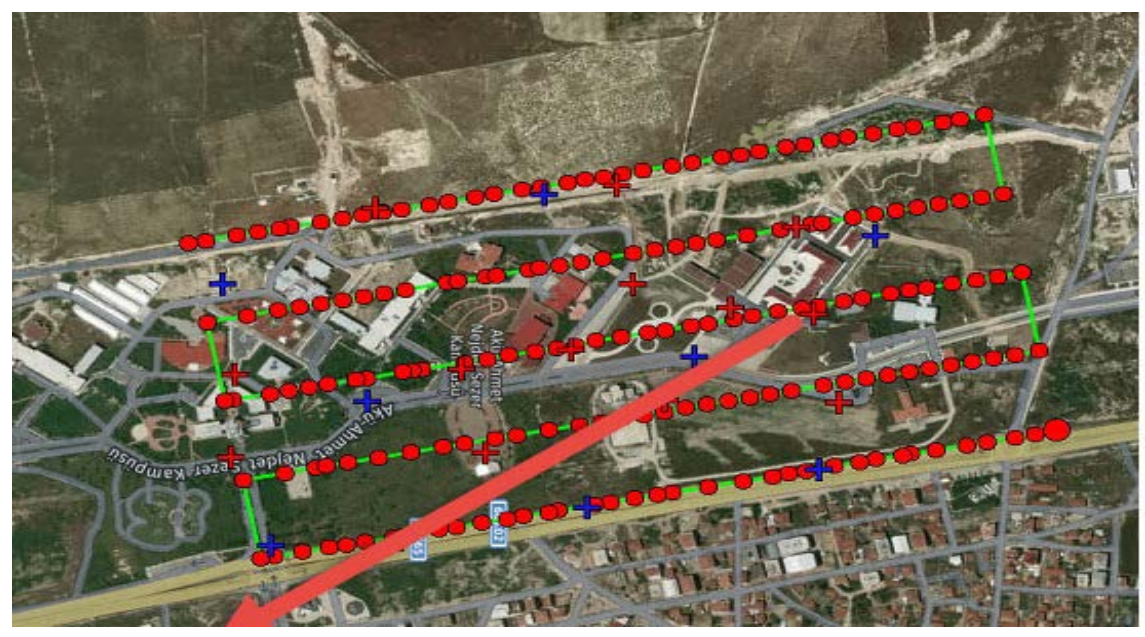

Şekil 2. İHA'nın çalışma alanındaki uçuş yolu

\subsection{Görüntü İşleme}

İHA yardımıyla elde edilmiş olan hava fotoğrafları, Pix4D Mapper Pro yazılımında işlenmiştir. Bu sürecin temel amacı, üst üste binen hava görüntü verilerinin işlenmesiyle, coğrafi referanslı bir 3B nokta bulutu oluşturmaktır [5]. Görüntülerden nokta bulutu oluşturma yaklaşımı, Hareketin Yapısı (SfM) olarak adlandırılır. SfM, stereoskopik fotogrametri ile aynı temel koşullar altında çalışmaktadır. İlgili nesneye ait 3B bir görüntü elde etmek için örtüşen görüntüleri kullanmaktadır [13]. Bu yöntemde veri işleme nispeten daha kolaydır. Görüntü işleme, İHA’ya entegre olan fotoğraf makinesinden bilgisayara fotoğraf yükleme ve görüntülerden bozuk veya bulanık olanları işlemden çıkarma aşaması ile başlamaktadır.

\subsection{Doğruluk Analizleri}

Bilindiği gibi gerçek arazi yüzeyi kesintisizdir. Yani süreklilik arz eder. Gerçek arazinin fotogrametrik olarak elde edilmesi ve sayısal olarak kullanılması sırasında boş kalan alanlar var olan verilerden enterpolasyon ile hesaplanır. $\mathrm{Bu}$ durumda elde edilen üründen rast gele seçilen noktalar kullanılarak ortalama bir hata hesaplanması gerekir. Böylece üretilen ürünün gerçek araziden alınış referans verilere ne kadar uygun ya da yaklaşık olduğu kestirilerek sonuç ürünün doğruluğunu ifade için istatistik ve metrik bir değer elde edilmiş olur. Bu kapsamda haritacılık anlamında çoğunlukla Karesel Ortalama Hata (KOH) kullanılır. Çalışma kapsamında yatay ve düşey koordinat değerleri için KOH hesapları gerçek arazi yüzeyinden alınan referans ölçümler kullanılarak yapılııştır. Karesel Ortalama Hata (KOH) değerini elde etmek için eşitlik 1'deki denklem kullanılmaktadır.

$$
\mathrm{KOH}=\sqrt{\frac{\left(\mathrm{Z}_{\text {Model }}-\mathrm{Z}_{\mathrm{Ref}}\right)^{2}}{\mathrm{n}}}
$$

Burada $\mathrm{Z}_{\text {model }}$ üretilen modelin değerini, $\mathrm{Z}_{\text {Ref }}$ kontrol noktalarından gelen referans değerini ve $\mathrm{n}$ ise kontrol noktalarının sayısını göstermektedir.

\section{Bulgular}

Çalışma kapsamında iki temel fotogrametrik ürün elde edilmiştir. Bunlar ortofoto ve SYM'dir (Şekil 3). Çalışmanın bulgular kısmı, üretilen bu fotogrametrik ürünler için yapılan doğruluk analizi değerlerini içermektedir. Bu 


\section{Nevşehir Bilim ve Teknoloji Dergisi (2019), 8(1) 56-62}

değerler, İHA ile üretilen bu fotogrametrik ürünlerin kullanıcıya (yükseklik veya mesafe ölçümündeki yanılma payı gibi) hangi doğruluk düzeyinde bilgi sağlayacağının belirlenmesi için gereklidir.

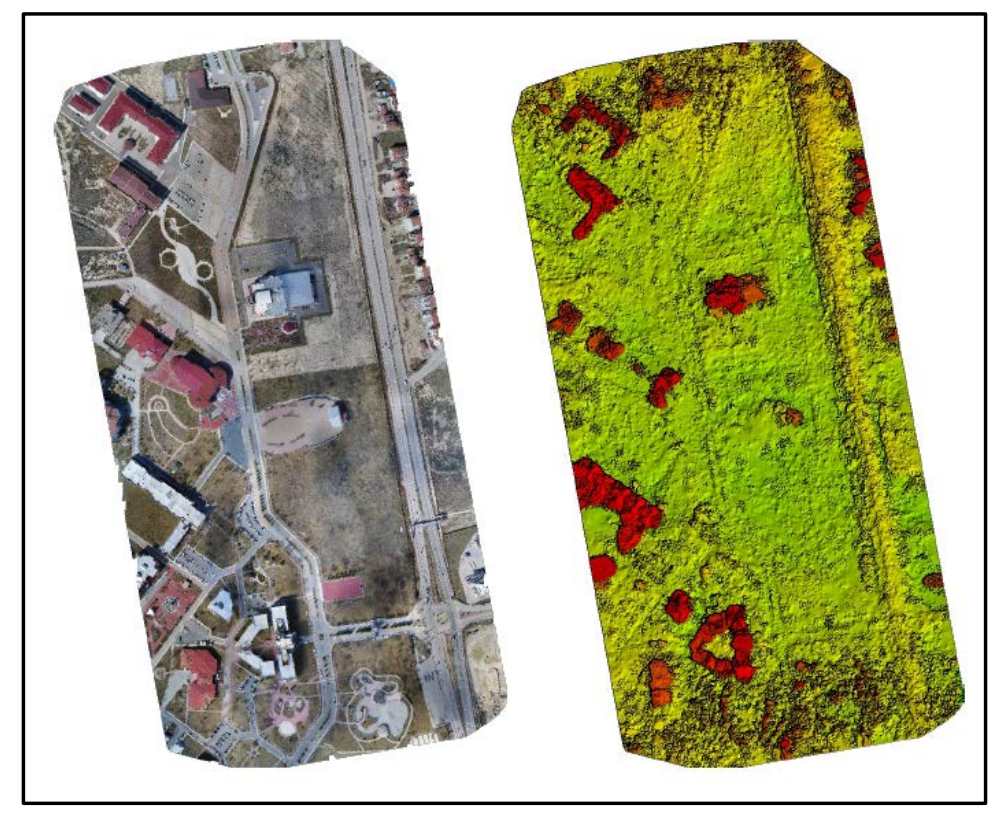

Şekil 3. Çalışma alanı için üretilen ortofoto (solda) ve SYM (sağda)

Ortofoto değerleri ve kontrol noktaları arasındaki koordinat farklılıkları kullanılan yazılım ile hesaplanmıştır. Çalışma kapsamında yer kontrol noktalarının koordinatları Stonex S9 GNSS aygıtı ile ölçülmüştür ve elde edilen hesaplama sonuçları Tablo 1'de verilmiştir.

\begin{tabular}{ccccccc}
\multicolumn{7}{c}{ Tablo 1. Koordinatlar için hesaplanan Karesel Ortala Hata (KOH) değerleri } \\
\hline $\begin{array}{c}\text { Kontrol } \\
\text { Noktaları }\end{array}$ & $\mathbf{X}_{\mathbf{G P S}}$ & $\mathbf{Y}_{\mathbf{G P S}}$ & $\mathbf{X}_{\text {orto }}$ & $\mathbf{Y}_{\text {ortho }}$ & $\mathbf{D} \mathbf{X ( m )}$ & $\mathbf{D ~ Y ( m ) ~}$ \\
1 & 4298466 & 546313,8 & 4298466 & 546313,8 & $-0,003$ & 0,023 \\
4 & 4298580 & 546324 & 4298580 & 546324 & $-0,011$ & 0 \\
5 & 4298617 & 546470 & 4298617 & 546470,1 & 0,012 & $-0,004$ \\
6 & 4298416 & 546396 & 4298416 & 546395,9 & $-0,018$ & 0,018 \\
7 & 4298375 & 546467,9 & 4298375 & 546467,9 & $-0,005$ & 0,024 \\
8 & 4298244 & 546384,8 & 4298244 & 546384,8 & $-0,042$ & 0,003 \\
9 & 4298330 & 546275,5 & 4298330 & 546275,5 & $-0,017$ & 0,028 \\
15 & 4297963 & 546473,5 & 4297963 & 546473,5 & $-0,005$ & $-0,009$ \\
16 & 4298093 & 546418,2 & 4298093 & 546418,2 & $-0,008$ & 0,015 \\
17 & 4298126 & 546558 & 4298126 & 546558 & 0,013 & 0,017 \\
18 & 4297775 & 546566,7 & 4297775 & 546566,7 & $-0,019$ & 0,036 \\
21 & 4298268 & 546648,6 & 4298268 & 546648,6 & $-0,009$ & $-0,014$ \\
& & & $\mathbf{K O H}$ & $\mathbf{0 , 0 1 8}$ & $\mathbf{0 , 0 2}$ \\
\hline
\end{tabular}

SYM ve kontrol noktaları arasındaki Z farklılıkları da ayrıca hesaplanmıştır. Aynı 12 kontrol noktası, Stonex S9 GNSS ile ölçülmüş ve hesaplama sonuçları Tablo 2'de verilmiştir. 
Nevşehir Bilim ve Teknoloji Dergisi (2019), 8(1) 56-62

Tablo 2. $\mathrm{Z}$ değerleri için hesaplanan Karesel Ortala Hata $(\mathrm{KOH})$ değerleri

\begin{tabular}{cccc} 
Kontrol Noktaları & $\mathbf{Z}_{\mathbf{G P S}}$ & $\mathbf{Z}_{\mathbf{S Y M}}$ & $\mathbf{D Z ( m )}$ \\
1 & 1047,974 & 1047,951 & 0,0229 \\
4 & 1048,426 & 1048,397 & 0,0293 \\
5 & 1048,698 & 1048,717 & $-0,0192$ \\
6 & 1047,999 & 1047,966 & 0,0333 \\
7 & 1048,384 & 1048,334 & 0,05 \\
8 & 1048,074 & 1048,059 & 0,015 \\
9 & 1048,42 & 1048,44 & $-0,0196$ \\
15 & 1047,88 & 1047,839 & 0,0406 \\
16 & 1047,92 & 1047,868 & 0,052 \\
17 & 1048,079 & 1047,96 & 0,1186 \\
18 & 1047,394 & 1047,38 & 0,0137 \\
21 & 1049,168 & 1049,079 & 0,0889 \\
& & $\mathbf{K O H}$ & $\mathbf{0 , 0 5 4}$ \\
\hline
\end{tabular}

Sonuç olarak, Tablo 1 ve Tablo 2'de verilen yatay ve düşey koordinatlar için elde edilmiş ortalama hata değerleri yatayda $2 \mathrm{~cm}$ ve düşeyde $5 \mathrm{~cm}$ olarak hesaplanmıştır. Bu değerlerin literatürdeki diğer çalışmalarda elde edilen yatay ve düşey doğruluk değerlerine çok yakın olması, çalışmanın tutarlılığı ve doğruluğunu göstermektedir. Ayrıca izlenen metodun İHA ile fotogrametrik olarak yükseklik modeli üretiminin yersel yöntemlere göre daha hızlı ve benzer doğrulukta olduğu görülmektedir.

\section{Tartışma ve Sonuç}

Bu makale, alternatif bir veri toplama teknolojisi olan İHA'ların, SYM jenerasyonu ile küçük bir alanda geomatik bir uygulamada kabiliyetini göstermektedir. Geleneksel insanlı hava platformları ile kıyaslandığında, bu yöntem çalışma maliyetlerini düşürmekte, riskli çalışma sahalarına ulaşma tehlikesini en aza indirmekte ve yeterli doğruluk sağlamaktadır. Bununla birlikte, İHA sistemlerinin sadece coğrafi değil, aynı zamanda çeşitli disiplinler için de çok önemli olan birçok avantajının olduğu (düşük maliyetli, gerçek zamanlı, yüksek zamansal ve mekansal çözünürlük vb.) bu çalışma ile vurgulanmaktadır. Uygulama, İHA ile entegre edilmiş dijital kamera sistemlerinin, ölçme uygulamaları için kullanılabilir verileri toplamasına olanak sağladığını göstermektedir. Bu çalışma sonucunda, İHA tabanlı verilerin, 5 mm dikey doğrulukta fotogrametrik tekniklerle SYM üretimi için kullanılabileceğini göstermektedir. Ayrıca İHA fotogrametrisinin mühendislik uygulamalarında düşük maliyet, zaman tasarrufu, minimum saha çalışması ve yeterli doğruluğu elde ettiği bu çalışma ile ortaya konmaktadır. Sonuç ürün olarak oluşturulan 3B model, topografyanın gerçek yapısını da çıkarmada oldukça başarılıdır.

\section{Kaynaklar}

[1] Aicardi I., Boccardo P., Chiabrando F., Facello A., Gnavi L., Lingua A., Pasquale F., Maschio P., Spanò A., 2014, “A didactic project for landscape heritage mapping in postdisaster management” Applied Geomatics, 7(1), 49-60, 2015

[2] Yastıklı N., Bağcı I., Beşer C., 2013, "The processing of image data collected by light UAV systems for GIS data capture and updating” ISPRS Archives, Volume XL-7/W2, 2013 ISPRS2013-SSG, 
[3] Toprak A. S., Polat N., Uysal M., 2019, “3D modeling of lion tombstones with UAV photogrammetry: a case study in ancient Phrygia (Turkey)” Archaeological and Anthropological Sciences May, Volume 11, Issue 5, pp 1973-1976

[4] Polat N. and Uysal M., 2017, “Dtm Generation With Uav Based Photogrammetric Point Cloud”, ISPRS Archives, p. 77-79

[5] Ulvi A., 2018, “Analysis of the utility of the unmanned aerial vehicle (Uav) in volume calculation by using photogrammetric techniques” Int. J. Eng. Geo., Cilt 3, Sayı 2, Sayfalar 43 - 49.

[6] Özcan, O., 2017, “İnsansız Hava Aracı ile Farklı Yüksekliklerden Üretilen Sayısal Yüzey Modellerinin (SYM) Doğruluk Analizi”, Mühendislik ve Yer Bilimleri Dergisi, 2 (1), 1-7.

[7] Akturk, E., and Altunel A. O., 2019, “Accuracy Assessment of a Low-Cost UAV Derived Digital Elevation Model (DEM) in a Highly Broken and Vegetated Terrain.” Measurement 136: 382-386

[8] Polat, N.; Uysal, M., 2018, “An Experimental Analysis of Digital Elevation Models Generated with Lidar Data and UAV Photogrammetry.” J. Indian Soc. Remote Sens., 46, 1135-1142

[9] Höfle B., Griesbaum L., Forbriger M., “GIS-Based Detection of Gullies in Terrestrial LiDAR Data of the Cerro Llamoca Peatland (Peru)” Remote Sensing, 5, 5851-5870, 2013

[10] Susaki J., 2012, “Adaptive Slope Filtering of Airborne LiDAR Data in Urban Areas for Digital Terrain Model (DTM) Generation” Remote Sensing, 4(6), 1804- 1819.

[11] Aicardi I., Dabove P., Lingua A.M., Piras M., 2017, "Integration between TLS and UAV photogrammetry techniques for forestry applications”, Iforest, 10 (1), pp. 41-47

[12] Birdal A.C., Avdan U., Turk T., 2017, "Estimating tree heights with images from an unmanned aerial vehicle” Geomat. Nat. Haz. Risk, 8 (2), pp. 1144-1156,

[13] Siebert S., Teizer J., 2014, “Mobile 3D mapping for surveying earthwork projects using an Unmanned Aerial Vehicle (UAV) system” Autom Constr. 1-14.

\section{Extended Abstract}

\section{Introduction}

Today, Unmanned Aerial Vehicles (UAVs) are widely used for different purposes in many applications. But the benefits can not be fully determined due to the integration capabilities of equipment such as digital cameras, GPS or laser scanners. The main goal of this study is the evaluation of the performance of integrated UAVs for geo-location cameras through the Digital Surface Model (DSM) production at Afyon Kocatepe University Campus. Afyon Kocatepe University was chosen as the study area. A large part of the Afyonkarahisar city, which houses the university, is located in the Aegean region. The areas to the east of the city show the characteristics of the Central Anatolian region. However, it is possible to see features of the Mediterranean region in a very small area on the south-west. Afyonkarahisar province is an intersection point connecting cities.

In the study, 5 ground control points and 12 control points were marked and examined with RTK. A photogrammetric flight plan was then made and 274 aerial photographs were taken from an altitude of $120 \mathrm{~m}$ with an rate of overlay of $80 \%$. After processing the image, a high resolution DSM with a $50 \mathrm{~cm}$ pixel size was produced and the DSM was calculated as $5 \mathrm{~cm}$.

\section{Method}

DJI Phantom 4 pro UAVs was used for the study. 274 aerial photographs were taken from an altitude of $1100 \mathrm{~m} \times 500 \mathrm{~m}$ and a height of $120 \mathrm{~m}$. In this study, image processing and accuracy analysis were performed. The aerial photographs obtained with the help of the IHA have been processed in the Pix4D Mapper Pro software. The main purpose of this process is to create a geographically referenced 3D point cloud by processing superimposed aerial images. The approach of creating point clouds from images is called Motion Structure (SfM). SfM operates under the same basic conditions as stereoscopic photogrammetry. It uses overlapping images to get a 3D image of the object in question. 


\section{Nevşehir Bilim ve Teknoloji Dergisi (2019), 8(1) 56-62}

Accuracy analysis of height information obtained by UAVs was also performed in the study. Five new control points are used in the RMS equation to obtain the value of Z's Root Mean Square (RMS). The corresponding table values are shown in the article.

\section{Results and Discussion}

Today, documentation technologies based on advanced geomatic engineering tools provide significant support for updated maps. In the scope of the study, orthophoto and SYM images of the field of study were obtained. Coordinate differences were calculated using the software between orthophoto values and control points. Coordinates of ground control points were measured with Stonex S9 GNSS device. Z differences between DSM and control points are also calculated. Same 12 control points measured by Stonex S9 GNSS.

This article demonstrates the ability of UAVs, an alternative data collection technology, to generate a DSM generation in a small field geomatic application. Compared to traditional human air platforms, this method reduces operating costs, minimizes the risk of reaching risky work sites and provides sufficient accuracy. However, this study emphasizes that UAVs systems have many advantages not only geographically but also for various disciplines (low cost, real time, high temporal and spatial resolution etc.). The application demonstrates that digital camera systems integrated with UAVs allow the sum of the available data for measurement applications. As a result of this study, it is shown that UAVs-based data can be used for DSM production by photogrammetric techniques at $5 \mathrm{~mm}$ vertical accuracy. In addition, this study shows that UAVs photogrammetry achieves low cost, time saving, minimum field work and sufficient accuracy in engineering applications. The result is a $3 \mathrm{D}$ model, which is quite successful in removing the real structure of the topography. 